\title{
Syekh Mahfudz al-Tarmasi: Muhaddis Nusantara
}

\author{
Ahmad Fauzan \\ Progam Pascasarjana \\ Prodi Aqidah dan Filsafat Islam \\ UIN Sunan Kalijaga Yogyakarta \\ Email: afauzan757@gmail.com
}

\section{Abstrak:}

Artikel ini mengkaji tentang tokoh intelektual hadis nusantara yang karya-karyanya telah mendunia dengan latar belakang inspirasi dari fenomena tokoh-tokoh hadis nusantara yang terbilang begitu banyak seperti al-Raniri, Syekh Yasin al-Fadani, Syekh Hasyim Asy'ari dan Syekh Mahfud al-Tarmasi. Dalam tulisan ini secara khusus mengkaji salah satu tokoh hadis nusantara, yakni Syekh Mahfudz al-Tarmasi, baik dari sisi biografi, kontribusinya dalam bidang hadis, qira'ah, dan sanad. Metode yang digunakan dalam penulisan ini adalah konten analisis data dengan menggunakan studi literatur (library research). Hasil yang diharapkan dari tulisan ini bahwa keluasan keilmuan Syekh al-Tarmasi sebenarnya tidak terbatas pada disiplin hadis maupun ilmunya saja, akan tetapi juga pada disiplin ilmu lainnya seperti qira'ah, fikih dan lain sebagainya. Ulama-ulama Nusantara sebelum beliau juga banyak yang mempelajari hadis, namun perhatian yang mereka berikan tidak sebesar perhatian al-Tarmasi dalam disiplin hadis maupun ilmunya.

Kata Kunci : Hadis, al-Tarmasi, Muhaddis Nusantara

\section{Pendahuluan}

Kota Makkah dan Madinah sejak berabad-abad yang lampau merupakan tempat berkumpul para ulama-ulama terkemuka dari seluruh dunia, seperti Afrika Utara, kawasankawasan Arab lainnya seperti Mesir, Sudan, juga dari Asia Tenggara, India dan Indonesia. Di sanalah beliau-beliau 
menuntut ilmu dan memilih untuk menetap di Makkah dan Madinah dan kemudian menjadi tokoh ulama Haramain. ${ }^{1}$ Di antara sekian ulama Indonesia yang pernah melakukan rihlah ilmiyyah di Timur Tengah, ada sebagian di antara mereka yang secara khusus membidangi disiplin hadis maupun ilmunya, seperti Syekh Mahfudz al-Tarmasi yang merupakan salah satu ulama Nusantara di era akhir abad ke-19 yang aktif dan banyak menghasilkan karya dalam bidang berbagai ilmu pengetahuan. Dari sinilah kemudian dapat dijadikan sebagai titik awal terbentuknya jaringan ulama hadis Nusantara. ${ }^{2}$

Luasnya keilmuan al-Tarmasi sebenarnya tidak terbatas pada disiplin hadis maupun ilmunya saja, akan tetapi juga pada disiplin ilmu lainnya seperti qira'ah, fikih dan lain sebagainya. Beliau adalah yang paling perhatian terhadap disiplin hadis dibandingkan dengan ulama Indonesia lainnya, sehingga menjadikan beliau mendapat julukan sebagai pembangkit ilmu dirayah hadis, khususnya ilmu kritik sanad dan matan hadis. ${ }^{3}$ Atas keluasan ilmunya, al-Tarmasi menelurkan banyak karya ilmiah dalam berbagai bidang ilmu, khususnya bidang hadis maupun ilmunya. Di antara karya beliau, kitab 'Inayah alMuftaqir bima- Yata'allaq bi Sayyidina al-Khadhir, yang secara garis besar mendiskusikan polemik seputar sosok Nabi Khidir AS, kitab Manhaj Dzawin al-Nadzar yang merupakan kitab ilmu hadis yang menjelaskan bait-bait Syekh al-Suyuthi, dan kitab alMinhah al-Khairiyyah yang merupakan kitab kumpulan 40 hadis Rasulullah saw.

${ }^{1}$ Muhammad Nurdinah. "Karakteristik Jaringan Ulama Nusantara Menurut Pemikiran Azyumardi Azra". Jurnal Substantia, Vol. 14, NO. 1, April 2012, h.1.

2 Hasan Su'udi, “Jaringan Ulama Hadis Indonesia," Jurnal Penelitian STAIN Pekalongan. Vol. 5, No. 2, November 2008, h. 5.

${ }^{3}$ Hasan Su'udi. “Jaringan Ulama Hadis Indonesia," h. 3.

TAHDIS Volume 9 Nomor 2 Tahun 2018 
Mengingat besarnya kontribusi dan pengaruh al-Tarmasi dalam sejarah perkembangan Islam di Nusantara, khususnya dalam bidang hadis, maka kajian tentang tokoh besar ini sangat penting dilakukan. Tulisan ini akan memberikan gambaran tentang kontribusi pemikiran al-Tarmasi terkait dalam bidang sanad dan hadis.

\section{Riwayat Hidup Syekh Mahfudz al-Tarmasi}

\section{Biografi Syekh Mahfudz al-Tarmasi}

Nama lengkapnya adalah Muhammad Mahfudz bin 'Abdillah bin 'Abdul Manan bin Dipomenggolo al-Tarmasi alJawi. Beliau dilahirkan di Tremas, Pacitan, Jawa Timur, pada tanggal 12 Jumadil Awal 1285 H., ${ }^{4}$ yang bertepatan dengan tanggal 31 Agustus 1842 M. ${ }^{5}$ Beliau wafat di Makkah pada awal bulan Rajab pada malam Senin tahun $1338 \mathrm{H}$ dalam usia 53 tahun, dan dimakamkan di Maqbaroh al-Ma'la. ${ }^{6}$ Saat dilahirkan, ayah beliau sedang berada di Makkah yang sedang menunaikan haji sekaligus menuntut ilmu agama di sana, sebagaimana kebanyakan ulama Nusantara pada masa itu. ${ }^{7}$ Nisbat al-Tarmasi pada nama beliau merupakan penisbatan pada tempat asal kelahiran beliau, yakni desa Tremas, Arjosari, Pacitan, Jawa Timut. ${ }^{8}$

Al-Tarmasi adalah putra tertua dari Kyai Abdullah, adapun adik-adik kandung beliau adalah Kyai Dahlan, Nyai Tirib,

${ }^{4}$ Muhammad Mahfudz al-Tarmasi. Kifāyah al-Mustafid limā 'Alā min Asānīd, (Beirut: Darul Basyair al-Islamiyyah, 1408), h. 1.

5 Sutarto (dkk). Kumpulan 40 Hadis Syekh Mahfudz al-Tarmasi, (Yogyakarta: Lingkar Media, 2014), h. 1.

${ }^{6}$ Muhammad Mahfudz al-Tarmasi, 'Inayah al-Muftaqir bima- Yata'allaq bi Sayyidināal-Khadhir, (Demak: Al-Barokah PP. BUQ Betengan, 1428), h. 1.

7 Muhammad Muhajirin, Mahfudz al-Tarmasi: Ulama Hadis Nusantara Pertama, (Yogyakarta: Idea Press, 2016), h. 25.

8 Muhammad Muhajirin, "At-Tarmasi: Icon Baru Hadits Arbai'in di Indonesia." ASILHA International Conference 2017, h. 313. 
Kyai Dimyati yang juga pernah belajar di Makkah serta ahli dalam Ilmu waris, Kyai Muhammad Bakri yang ahli Qira'ah, Sulaiman Kamal, Muhammad Ibrahim, dan Kyai Abdurrazaq yang merupakan ahli Thoriqat dan seorang Mursyid thoriqah yang mempunyai pengikut di seluruh Jawa. ${ }^{9}$ Keluarga alTarmasi merupakan keturunan dari keluarga pesantren, yakni pesantren Pondok Tremas Pacitan yang didirikan oleh kakeknya, yakni Kyai Abdul Manan. Beliau menikmati masa kecilnya di lingkungan Pesantren Tremas yang saat itu (masa kecil al-Tarmasi) pondok Tremas di asuh oleh ayahnya, yakni Kyai Abdullah. Karena hidup di lingkungan pesantren, alTarmasi diperkenalkan dengan nilai-nilai serta praktek keagamaan oleh ibu dan pamannya, Athaillah. ${ }^{10}$

Nuansa pesantren yang setiap harinya menghadirkan nuansa keilmuan, tentunya sangat mempengaruhi kepribadian al-Tarmasi akan kecintaannya terhadap ilmu pengetahuan, khususnya ilmu agama dan menghantarkannya menjadi seorang pelajar sekaligus pendidik. Bahkan dijelaskan bahwa al-Tarmasi sudah hafal al-Qur'an sebelum usia dewasa, yakni pada usia 6 tahun di bawah bimbingan dan asuhan ibu dan pamannya. ${ }^{11} \mathrm{Di}$ satu sisi pada usia 6 tahun, di ajak oleh ayahnya ke Makkah pada tahun 1291 H/ 1874 M di Makkah. sang ayah memperkenalkan beberapa kitab penting kepadanya. ${ }^{12}$ dan pada usia 12 tahun kembali ke Nusantara bersama ayahnya tepatnya pada tahun 1878 M. ${ }^{13}$ Atas asuhan ayahnya ini sehingga al-Tarmasi

${ }^{9}$ Sutarto (dkk). Kumpulan 40 Hadis Syekh Mahfudz al-Tarmasi, h. 2.

10 Muhammad Muhajirin, Mahfudz al-Tarmasi: Ulama Hadis Nusantara Pertama, h. 27.

11 Muhammad Muhajirin, Mahfudz al-Tarmasi: Ulama Hadis Nusantara Pertama, h. 28.

12 Muhammad Mahfudz al-Tarmasi. Kifāyah al-Mustafid lima' 'Alämin Asānìd, h. 41 .

13 Muhammad Muhajirin, Mahfudz al-Tarmasi: Ulama Hadis Nusantara Pertama, h. 32.

TAHDIS Volume 9 Nomor 2 Tahun 2018 
menganggap ayahnya lebih dari sekedar seorang ayah dan guru, tentang ayahnya, Syekh Mahfudz menyebutnya sebagai murabbī wa ruhị (pendidikku dan jiwaku). ${ }^{14}$

\section{Pendidikannya di Nusantara}

Sejak usia dini, beliau mempelajari kitab-kitab kepada ayah beliau sendiri, di antaranya adalah kitab Syarh al-Ghayah li Ibni Qasim al-Ghuzza, al-Manhaj al-Qawim, Fath al-Mu'in, Fath alWahab, Syarh Syarqawiy 'ala al-Hikam, dan sebagian Tafsir alJalalain hingga Surat Yunus. ${ }^{15}$ Merasa haus akan ilmu dan setelah memperoleh ilmu dari orang tuannya sendiri, pada tahun 1878 M setelah kembalinya dari Makkah bersama ayahnya, al-Tarmasi berpindah ke Semarang dan belajar kepada Kyai Muhammad Shaleh Darat. ${ }^{16}$ Di antara kitab-kitab yang dipelajari kepada Kyai Shaleh Darat adalah Syarh al-Hikam (dua kali hatam), Tafsir al-Jalalain (dua kali hatam), Syarh al-Mardini dan Wasilah al-Tullab (kitab yang membahas mengenai ilmu falak). ${ }^{17}$

Pada usia 23 tahun setelah tamat dari Pesantren Kyai Shaleh Darat, al-Tarmasi rindu akan nuansa Haramain yang pernah menjadi tempat bermain dan belajarnya bersama ayahnya, di tambah doktrin Kyai Shaleh Darat sebagai guru sekaligus ulama produktif yang pernah belajar di Haramain, membuat al-Tarmasi berkeinginan untuk ke Haramain untuk yang kedua kalinya guna melanjutkan studinya di sana. ${ }^{18}$ Cara al-

${ }^{14}$ Sutarto (dkk). Kumpulan 40 Hadis Syekh Mahfudz al-Tarmasi, h. 2.

${ }^{15}$ Hayati Hussin (dkk.), "al-Tarmasi: Tokoh Prolifik Dalam Bidang Pengajian Islam," Jurnal Pengajian Islam. Akademi Islam Kuis. 2 November 2015, h. 195-196.

16 Muhammad Muhajirin, Mahfudz al-Tarmasi: Ulama Hadis Nusantara Pertama, h. 32.

17 Sabri Mohamad (dkk), "Syeikh Mahfudz al-Tarmasi: Tokoh Ilmu Qira'at Nusantara," Prosiding Nadwah Ulama Nusantara (NUN) IV, 25-26 November 2011, h. 542.

18 Muhammad Muhajirin, Mahfudz al-Tarmasi: Ulama Hadis Nusantara Pertama, h. 32-33. 
Tarmasi dalam mendapatkan pengetahuan bervariasi, terkadang beliau memusatkan perhatiannya pada apa yang diuraikan oleh guru. Yang paling sering, beliau membaca kitab di hadapan gurunya dilanjutkan dengan menunggu koreksi dan komentar gurunya. ${ }^{19}$ Beliau merupakan murid yang dinamis, antusiasnya untuk memperkaya diri dengan ilmu pengetahuan Islam ditampakkan beliau kepada guru-guru yang ditemuinya dengan dua cara tersebut.

\section{Rihlah Ilmiah di Haramain}

Pada tahun $1308 \mathrm{H}$, al-Tarmasi mulai mengadakan rihlah ilmiyah ke Haramain untuk kedua kalinya. Suasana religius yang pernah dirasakannya pada masa kecil, membuat semangat baru dan ghirah yang tinggi al-Tarmasi untuk mendalami ilmu agama di sana. ${ }^{20}$ Selama di Makkah, beliau mendalami benyak disiplin ilmu agama, tidak hanya hadis yang kemudian menjadi spesialisasinya, tetapi juga berbagai ilmu agama lainnya, yakni dengan bukti karya yang dihasilkannya, seperti ilmu qira'ah dan lain sebagainya. ${ }^{21}$

Secara historis, sejak abad 16 hingga awal abad 20 dunia pendidikan Haramain dikenal dengan istilah halaqah (murid duduk mengelilingi guru). Lingkaran pelajar semacam ini di adakan di sekitar serambi Masjidil Haram dan juga Masjid Nabawi di Madinah. Selain itu juga ada istilah ribath semacam pondoan dan juga kuttab berupa madrasah kecil yang diselenggarakan di rumah-rumah para pengajar. Di tempattempat inilah para pelajar dari penjuru dunia dan Nusantara, tak

${ }^{19}$ Sutarto (dkk). Kumpulan 40 Hadis Syekh Mahfudz al-Tarmasi, h. 3.

20 Muhammad Muhajirin, Mahfudz al-Tarmasi: Ulama Hadis Nusantara Pertama, h. 39.

21 Muhammad Muhajirin, Mahfudz al-Tarmasi: Ulama Hadis Nusantara Pertama, h. 40. 
terkecuali al-Tarmasi, belajar dan mengkaji al-Qur'an, tafsir, hadis, fikih, ilmu bahasa Arab dan keilmuan Islam lainnya. ${ }^{22}$

Tempat pengajian -seperti di sebut di atas- kerap dikunjungi oleh al-Tarmasi guna memperdalami ilmu agama. Nama beliau mulai dikenal karena kegigihan, keseriusan, dan ketekunannya dalam mempelajari hadis dengan seorang guru yang cukup ternama pada masa itu, yakni Syekh Muhammad Syatha al-Makki. Bahkan beliau diangkat menjadi bagian dari keluarga gurunya ini.23 Pada saatnya, menjadikan beliau memiliki posisi sosial keagamaan yang cukup terhotmat dan bahkan diberi kesempatan untuk mengajar di Masjidil Haram yang ketika itu tidak semua orang bisa melakukan ataupun mendapatkan ijazah untuk mengajar di Masjidil Haram sejak tahun 1890 M.24

Pada paruh akhir abad ke 19, ada beberapa ulama dari Nusantara Indonesia yang kepakaran dan keilmuannya di bidang agama diakui di dunia Islam, mereka diberi kesempatan seluas-luasnya untuk mengajarkan ilmunya di Masjidil Haram. Setidaknya ada tujuh ulama Nusantara yang terkemuka dikenal luas, yakni Syekh Mahfudzz al-Tarmasi (Jawa Timur), Syekh Nawawi al-Bantani (Jawa Barat), Syekh Ahmad Khatib alMinangkabawi (Sumatra Barat), Syekh Muhtaram Banyumas (Jawa Tengah), Syekh Bakir Banyumas (Jawa Tengah), Syekh Asy'ari Bawean (Jawa Timur), dan Syekh Abdul Hamid Kudus (Jawa Tengah). ${ }^{25}$

Pada awal abab 20, al-Tarmasi menikah dengan Nyai Muslimah, seorang putri asal Demak, Jawa Tengah yang kala itu

22 Muhammad Muhajirin, Mahfudz al-Tarmasi: Ulama Hadis Nusantara Pertama, h. 40.

23 Muhammad Muhajirin, Mahfudz al-Tarmasi: Ulama Hadis Nusantara Pertama, h. 41.

${ }^{24}$ Sutarto (dkk). Kumpulan 40 Hadis Syekh Mahfudz al-Tarmasi, h. 9.

25 Sutarto (dkk). Kumpulan 40 Hadis Syekh Mahfudz al-Tarmasi, h. 7-8. 
sedang menunaikan haji. ${ }^{26}$ Beliau memiliki dua orang putri dan satu orang putra, hasil dari buah cintanya dengan istrinya Nyai Muslimah. Kedua putrinya meninggal saat berumur 5 tahun, dan hanya putranya yang bernama Muhammad yang masih hidup yang pada akhirnya menjadi pendiri Pondok BUQ Betengan, Demak. ${ }^{27}$ Sejak rihlahnya yang kedua kalinya ini, beliau belajar dan mengajar di Makkah hingga akhir hayatnya. Beberapa rekannya yang belajar di Makkah telah banyak yang kembali ke Nusantara lagi -seperti Kyai Dimyati (adik beliau), dan Kyai Kholil bangkalan, Madura- guna mengembangkan pesantren dengan keilmuannya di tempatnya masing-masing. ${ }^{28}$

Ciri khas al-Tarmasi saat mengajar di Masjidil Haram, beliau duduk pada tempat tertentu di dalam Masjidil Haram seraya menghadap Ka'bah, serta kemahirannya dalam menggunakan bahasa Arab secara fasih yang sering diselingi dengan bahasa Jawa. Metode belajar dan mengajar yang dipakai ada tiga macam. Pertama, guru membaca kemudian menjelaskan. Kedua, guru membaca kemudian murid menjelaskan. Ketiga, murid membaca dihadapan guru lalu sang guru memberikan koreksi terhadap bacaan murid dan juga dilakukan tanya jawab antara guru dan murid. ${ }^{29}$

\section{Guru-guru dan Murid-murid al-Tarmasi}

Al-Tarmasi semasa menuntut ilmu baik saat masih di Nusantara maupun di Haramain, beliau tekuni kepara guru-guru yang ahli dalam berbagai bidang ilmu. Guru-guru beliau merupakan beberapa ulama pilihan pada masanya, serta beberapa ulama yang berasal dari berbagai disiplin ilmu

${ }^{26}$ Sutarto (dkk). Kumpulan 40 Hadis Syekh Mahfudz al-Tarmasi, h. 3.

27 Muhammad Muhajirin, Mahfudz al-Tarmasi: Ulama Hadis Nusantara

Pertama, h. 34-37.

${ }^{28}$ Sutarto (dkk). Kumpulan 40 Hadis Syekh Mahfudz al-Tarmasi, h. 3.

29 Sutarto (dkk). Kumpulan 40 Hadis Syekh Mahfudz al-Tarmasi, h. 9.

TAHDIS Volume 9 Nomor 2 Tahun 2018 
pengetahuan, seperti fikih, hadis, tafsir, ilmu bahasa Arab, ilmu qiraat. ${ }^{30}$ Di antara guru-guru beliau saat menuntut ilmu, baik di Nusantara maupun di Haramain adalah Kyai Abdullah (ayah beliau), Kyai Shaleh Darat, Syekh Muhammad al-Syarbini alDimyati, Sayyid Abu Bakar bin Muhammad Zainal Abidin Shata al-Makky, Syekh Muhammad al-Munsyawi yang dikenal sebagai muqri, Syekh Umar bin Barakat al-Syami al-Biqa'ily al-Azhary alMakky al-Syafi'i, Syekh Mustafa bin Muhammad bin Sulaiman alAfifi, al-Habib Husain bin Muhammad bin Husain al-Habsyi alSyafi'i, Syekh Muhammad Said Babasil al-Hadrami al-Syafi'i alMakky, Sayyid Ahmad Zawawi al-Makky, Syekh Muhammad alSyarbini al-Dimyati, Sayyid Muhammad Amin bin Ahmad Ridwan al-Madani, dan lain-lain. ${ }^{31}$

Dari kesekian banyak guru al-Tarmasi, ada satu guru beliau yang memberikan andil besar dalam mengantarkan beliau menjadi seorang ulama Nusantara yang lebih dikenal dalam bidang hadis, beliau adalah Sayyid Abu Bakar bin Sayyid Muhammad Syatha. Selain ssebagai seorang guru, Abu Bakar Syatha juga sebegai ayah angkat al-Tarmasi yang banyak membimbing dan memberikan pengaruh besar atas keberhasilannya al-Tarmasi mencapai gelar ulama Nusantara yang berkaliber internasional. Kepadanya al-Tarmasi tidak kurang dari 4 kali menghatamkan shahih Bukhori, dan tentunya menghabiskan waktu yang cukup lama. ${ }^{32}$ Selain Abu Bakar Syatha, Sayyid Husain al-Habsyi dan juga Syekh Muhammad Said al-Hadrami juga mempunyai andil besar dalam menjadikan alTarmasi sebagai muhaddis yang tidak hanya menguasai Shahih

${ }^{30}$ Sutarto (dkk). Kumpulan 40 Hadis Syekh Mahfudz al-Tarmasi, h. 4.

${ }^{31}$ Hayati Hussin (dkk.), "al-Tarmasi: Tokoh Prolifik Dalam Bidang Pengajian Islam," h. 197-198.

32 Muhammad Muhajirin, Mahfudz al-Tarmasi: Ulama Hadis Nusantara Pertama, h. 55. 
Bukhari, tetapi juga kutub al-Sittah lainnya, termasuk syarh alfiah al-Suyuthi. ${ }^{33}$

Setiap guru yang tersebut bersambung kepada ulama yang lebih ke atas dinamakan sanad atau silsilah. Mengenai hal ini, al-Tarmasi mencatatnya dengan lengkap dalam kitabnya Kifayat al-Mustafid. Dan dalam tulisannya ini, beliau menyebutkan bahwa ilmu terbanyak yang diperoleh beliau adalah dari guru beliau Sayyid Abu Bakar Shata. ${ }^{34}$ Menurut Syekh al-Marsafi, al-Tarmasi adalah seorang yang terkenal degan pribadi yang berakhlak mulia, ramah tamah sewaktu berbicara dengan orang lain, tidak mencampuri urusan orang lain yang tidak ada kitannya dengan beliau, dan rumahnya di Makkah tidak pernah sepi dari orang-orang yang ingin belajar kepada beliau. ${ }^{35}$

Beliau juga memiliki banyak murid-murid yang handal dan alim, bukan saja dari kalangan pelajar Nusantara, bahkan dari seluruh benua termaksud dari kalangan Arab sendiri pada masa itu. ${ }^{36}$ Di antara murid-murid beliau yang berasal dari luar Nusantara, adalah Syekh Sa'adullah al-Maimani, seorang mufti dari Bombay India, Syekh Umar bin Hamdan seorang ahli hadis dari Haramain, al-Shihab Ahmad bin Abdullah, seorang muqri dari Syiria. ${ }^{37}$ Adapun di antara murid-murid beliau asal Nusantara adalah, Kyai Hasyim Asy'ari, Kyai Wahab Hasbullah dari Jombang, Muhammad Bakir bin Nur dari Yogyakarta, Kyai

33 Muhammad Muhajirin, Mahfudz al-Tarmasi: Ulama Hadis Nusantara Pertama, h. 56.

${ }^{34}$ Muhammad Mahfudz al-Tarmasi. Kifāyah al-Mustafid lima' 'Alāmin Asānid, h. 8 .

35 Sabri Mohamad (dkk), “Syeikh Mahfudz al-Tarmasi: Tokoh Ilmu Qira'at Nusantara," h. 542.

${ }^{36}$ Hayati Hussin (dkk.), "al-Tarmasi: Tokoh Prolifik Dalam Bidang Pengajian Islam," h. 198.

37 Muhammad Muhajirin, Mahfudz al-Tarmasi: Ulama Hadis Nusantara Pertama, h. 58.

TAHDIS Volume 9 Nomor 2 Tahun 2018 
R. Asnawi dari Kudus, Mu'ammar bin Kyai Baidawi dari Lasem, Ali bin Mahmud bin Muhammad Arsyad bin Abdullah al-Banjari, K.H Muhammad Dimyati al-Tarmasi yang merupakan adik kandung beliau, Umar bin Abi Bakr bin Abdullah bin Umar bin Ali bin Muhammad al-Bajind al-Hadrami al-Maliky, Muhammad Habib bin Abdullah bin Ahmad al-Shanqity, dan lain sebagainya. ${ }^{38}$

\section{Karya Intelektual}

Al-Tarmasi merupakan seorang penulis yang produktif, beliau mengarang sejumlah kitan tentang berbagai ilmu keislaman, seluruhnya ditulis dalam bahasa Arab. Dalam menulis, keilmuan al-Tarmasi ibarat sungai yang airnya terus mengalir tanpa henti. Kecepatannya dalam menulis dapat disebut istimewa, seperti kitab Manhaj Dawi al-Nadhar, beliau hanya menyelesaikan tulisan dalam kitab ini selama 4 bulan 14 hari. Beliau banyak menghabiskan waktunya di gua Hiro tempat Nabi Muhammad saw menerima wahyu Allah untuk mencari inspirasi dan menulis. ${ }^{39}$

Karya-karya beliau yang diterbitkan diantaranya adalah, ${ }^{40}$ pertama, bidang Fiqh dan Ushul Fiqh, yaitu: al-Siqayah al-Mardiyah fi Asma al-Kutb al-Fiqhiyyah al-Syafi'iyyah, Nail alMa'mul bi Hasyiyah Ghayah al-Wusul fi Ilm al-Usul, al-Is'af alMatholi bi Syarh Badr al-Lami' Nadham Jam' al-Jawami, Hasyiah Takmilah al-Manhaj al-Qawim ila Faraid, Mauhibbah Zi al-Fadl 'Ala Syarh Muqaddimah bi al-Fadl, Tahyi'at al-Fikr bi Syarh Alfiyah al-Syair. Kedua, bidang Tafsir, yaitu Fath al-Khabir bi Syarh Miftah al-Tafsir. Ketiga, bidang Hadis dan Ulumul Hadis,

${ }^{38}$ Hayati Hussin (dkk.), "al-Tarmasi: Tokoh Prolifik Dalam Bidang Pengajian Islam," h. 198.

${ }^{39}$ Sutarto (dkk). Kumpulan 40 Hadis Syekh Mahfudz al-Tarmasi, h. 22.

${ }^{40}$ Hayati Hussin (dkk.), "al-Tarmasi: Tokoh Prolifik Dalam Bidang Pengajian Islam," h. 199-200. 
yaitu Manhaj Dzawi al-Nadhar Syarh Mandhumah al-Asar, alKhil'ah al-Fikriyyah bi Syarh al-Minhah al-Khairiyyah, al-Minhah al-Khairiyyah fi Arba'in Hadisan Min Ahadis Khair al-Bariyyah, Shulashiat al-Bukhari, Inayah al-Muftaqir fima- Yata'allaq bi Sayyidina- al-Khidr, Bughyah al-Adzkiya' fi al-Bahs 'an Karāmah al-Auliya'. Keempat, bidang Sanad, yaitu Kifayah al-Mustafid fima 'Ala Min al-Sanid. Kelima, bidang Qira'at, yaitu , Insyirah al-Fuadi fi Qira'at al-Imām Hamzah, Ta'mīm al-Manāfi fi Qiraat al-Imām Näfi', Tanwïr al-Shadr fi Qira'at al-Imām Abi Amru, al-Badr alMunir fi Qiräat al-Imām Ibn Katsīr, al-Risalah al-Tarmasiyyah fi Asāinid al-Qira'at al-Asyriyyah, dan Ghunyah al-Thalabah bi Syarh Badr al-Lämi' Nazm Jam' al-Jawāwi. ${ }^{41}$

\section{Konstribusi Syekh Mahfudz At-Tarmasi}

\section{Kontribusi dalam bidang Sanad Qiro'ah}

Selain dikenal sebagai ulama ahli hadis dan ilmu hadis, alTarmasi juga dikenal sebagai maha guru Qira'ah al-Sab'ah, khususnya dari qiroah Imam al-Asyim. Selain dalam qiroah Imam Asyim, al-Tarmasi juga fasih dalam qiroah dari riwayat Imam Abi Umar al-Dani, Imam Ibnu Kasir, Imam Hamyah dan Imam Nafi'. Bahkan kemahiran beliau bukan hanya pada qiraah al-sab'ah saja, namun juga pada qira'ah 'asyroh. ${ }^{42}$ Saat ini sanad ijazah membaca al-Qur'an riwayat Imam Asyim baik pembacaan dengan cara melihat (bin-nadzor), maupun hafalan (bil-ghoib yang ada diberbagai pesantren, khususnya di Jawa, mayoritas melalui dua jalur sanad. Yang pertama dari Syekh Mahfudz alTarmasi yang bersambung kepada Imam Asyim, dan yang kedua

41 Muhammad Muhajirin, Mahfudz al-Tarmasi: Ulama Hadis Nusantara Pertama, h. 68.

42 Sutarto (dkk). Kumpulan 40 Hadis Syekh Mahfudz al-Tarmasi, h. 21.

TAHDIS Volume 9 Nomor 2 Tahun 2018 
dari Syekh Arwani Kudus, dari Syekh Muhammad Munawwir, dari Syekh Yusuf al-Dimyati bersambung kepada Imam Ayim. ${ }^{43}$

\section{Kontribusi dalam Bidang Hadis.}

Intelektualitas Syekh Mahfudz al-Tarmasi terbilang gemilang dan diakui secara internasional di kalangan para ulama. Kegemilangannya ini dapat dilihat dari karya-karya yang berhasil dibukukan dalam kitab-kitabnya, yang salah satunya adalah bidang hadis dan ulumul hadis. ${ }^{44}$ Beliau memiliki ciri khas keunikan tersendiri di dalam menyusun kitabnya, yakni, beliau selalu menyertakan sanad beliau dari fans ilmu yang akan ditulisnya, bahkan saat menyususun kitab al-Minhah alKhairiyah, beliau mengutamakan hadis-hadis dengan sanad yang tinggi (isnad 'adli). ${ }^{45}$

Suasana keilmuan dan religius kota Makkah kala itu yang menjadi dambaan bagi para pencari ilmu, memberikan semangat tersendiri bagi al-Tarmasi dalam mempelajari berbagai ilmu agama, khususnya keistiqomahan beliau untuk mendalami hadis. Menurut beliau ilmu hadis merupakan sentral atau tempat kembalinya segala ilmu pengetahuan, karena ia merupakan ilmu mutlak yanng dibutuhkan setian insan yang beriman kepada Allah dan RasulNya. Dan juga dapat dikatakan bahwa ilmu fiqih dalam menentukan suatu hukum juga merujuk petunjuk Rasulullah saw berdasarkan hadis-hadisnya, bahkan juga al-Qur'an yang butuh dengan penjelasan hadis Rasulullah saw. ${ }^{46}$ Oleh karena itu Pentingnya pengetahuan sanad memberikan isyarat kepada siapa saja yang tidak

${ }^{43}$ Sutarto (dkk). Kumpulan 40 Hadis Syekh Mahfudz al-Tarmasi, h. 20.

44 Muhammad Muhajirin, Mahfudz al-Tarmasi: Ulama Hadis Nusantara Pertama, h. 75.

45 Muhammad Mahfudz al-Tarmasi, Al-Khil'ah al-Fikriyyah bi Syarkh alMinḥah al-Khairiyyah, (Demak: Al-Barokah PP. BUQ Betengan, 2008), h. 1.

46 Muhammad Muhajirin, Mahfudz al-Tarmasi: Ulama Hadis Nusantara Pertama, h. 41. 
mengetahuinya secara baik akan mengantarkan padanya untuk menyatakan hal yang semena-mena, bahwa ini dan itu adalah hadis nabi, perbuatan nabi, dicontohkan nabi dan lain sebagainya. Akibatnya mereka tidak hanya terjebak dengan hadis dha'if (lemah) dan bahkan maudhu' (palsu). ${ }^{47}$

Sebagai orang yang tekun mempelajari bidang hadis secara khusus, al-Tarmasi menyadarkan dan mengingatkan dirinya sendiri dan yang lainnya tentang bahayanya menyampaikan hadis yang tidak jelas sumbernya atau bahkan palsu dengan merujuk pada sabda Nabi saw "Barang siapa yang berdusta dengan dan atau atas namaku, maka tempatnya yang paling layak adalah di Neraka."48 Dalam rangka inilah al-Tarmasi menspesialisasikan dirinya dalam ilmu hadis dan mempertahankannya sebagai salah satu tujuan utama ilmu studinya, dan juga dipengaruhi kondisi sosial keagamaan di Haramain dan juga Mesir pada waktu itu. ${ }^{49}$

Atas kegigihan dan keuletan al-Tarmasi ini menjadikan beliau dikenal sebagai ahli hadis, baik di kalangan Nusantara maupun Dunia, dan juga diakui sebagai seorang isnad (mata rantai) yang sah pada urutan ke 23 dalam trasnisi intelektual pengajaran Shohih Bukhori. Ijazah ini berasal langsung dari Imam Bukhori sendiri yang lalu diserahkan secara barantai melalui 23 generasi ulama yang telah menguasai Shohih Bukhori. ${ }^{50}$ Beliau memberikan pernyataan bahwa kemurnian isnad adalah hal yang sangat menyakinkan bagi mereka yang menguasai ilmu pengetahuan. Beliau dalam sebuah karya kitabnya mengawali kata-katanya dengan ungkapan "sungguh

47 Muhammad Muhajirin, Mahfudz al-Tarmasi: Ulama Hadis Nusantara Pertama, h. 43.

48 Sutarto (dkk). Kumpulan 40 Hadis Syekh Mahfudz al-Tarmasi, h. 18.

49 Muhammad Muhajirin, Mahfudz al-Tarmasi: Ulama Hadis Nusantara Pertama, h. 44.

${ }^{50}$ Sutarto (dkk). Kumpulan 40 Hadis Syekh Mahfudz al-Tarmasi, h. 12.

TAHDIS Volume 9 Nomor 2 Tahun 2018 
dimuliakan oleh Allah mereka yang ahli ilmu isnad dari umat ini (tidak seperti umat lain sebelum Nabi Muhammad)".51 Beliau juga mengutip pendapat Ibnu Sirrin bahwa isnad merupakan bagian dari agama, termaksud pendapat ulama salaf lainnya yang menyatakan bahwa isnad ibarat pedang tajam, apabila gagal dalam penggunaannya akan memberikan akibat fatal. Artinya, bagaimana mungkin seseorang akan memenangkan peperangan, jika memegang pedang saja ia tidak pandai. ${ }^{52}$

Sebagai seorang musnid dan muhaddits, al-Tarmasi memperoleh pengakuan untuk mentransfer koleksi hadis tidak hanya dari Bukhari, tetapi juga dari para pemberi ijazah lainnya. Para ulama tersebut beserta karya-karyanya adalah sebagai berikut; Shahih Muslim (w. 261 H), Sunan Abu Daud (w. 275 H), Sunan al-Tirmidzi (w. 279 H), Sunan al-Nasa'i (w. 303 H), Sunan Ibnu Majah (w. 273 H), Muwattha Malik bin Anas (w. 179 H), Musnad al-Syafi'i (w. 204 H), Musnad Imam Abu Hanifah (w. 150 H), Musnad Ahmad bin Hambal (w. 241 H), Mukhtashar bin Abu Jumra (w. 695 H), Arbain al-Nawawi (w. 676 H), Al-Jami Shagir oleh Ali bin Ibrahim al-Halabi (w. 1044 H). ${ }^{53}$

Salah satu dari kesekian banyak silsilah isnad Syekh Mahfudz dalam bidang hadis adalah isnadnya hingga Imam Bukhari yang beliau tulis dalam karya beliau kifayah al-mustafid, isnad tersebut adalah sebagai berikut; Syekh Mahfudz bin Abdullah al-Tarmasi dari Syekh Muhammad Shatha al-Makky dari Syekh Ahmad bin Zaini Dahlan dari Syekh Utsman bin Hasan al-Dimyati dari Syekh Muhammad bin Ali bin Manshur alSyanwani dari Syekh Aba al-Azaim Isa bin Ahmad al-Barāwi dari

51 Muhammad Mahfudz al-Tarmasi, Al-Khil'ah al-Fikriyyah bi Syarkh alMinh\}ah al-Khairiyyah, h. 1.

52 Muhammad Muhajirin, Mahfudz al-Tarmasi: Ulama Hadis Nusantara Pertama, h. 42.

${ }^{53}$ Sutarto (dkk). Kumpulan 40 Hadis Syekh Mahfudz al-Tarmasi, h. 17. 
Syekh Ahmad al-Dafri dari Syekh Salim bin Abdullah Al-Basri dari Syekh Abdullah bin Salim al-Basri dari Syekh Muhammad bin Ala al-din al-Babili dari Syekh Salim Muhammad bin alSanhuri dari Syekh al-Najm Muhammad bin Ahmad al-Ghaiti dari Syekh Islam Abi Yahya Zakariya bin al-Anshri dari Syekh alHafid al-Syihabu al-Din Ahmad bin Hajar al-Asqalani dari Syekh Ibrahim bin Ahmad al-Tanuhi dari Syekh Abi al-Abbas Ahmad bin Thalib al-Hajar dari Syekh al-Husain bin al-Mubarik alZubaidi al-Hanbali dari Syekh Abu al-Waqt Abdu al-Awwal bin Isa bin Syuaib al-Sijziy al-Harawi dari Syekh Abi al-Hasan Abdu al-Rahman bin Mudhaffar bin Dawud al-Dawudi dari Syekh Abi Muhammad Abdullah bin Ahmad al-Sarakhsi dari Syekh Abi Abdullah Muhammad bin Yusuf al-Firabri dari Syekh al-Imam alHafid Al-Hujja Abu Abdullah Muhammad bin Ismail bin Ibrahim al-Bukhari. ${ }^{54}$

Sebagai seorang ahli hadis terkemuka, tentunya karyakarya al-Tarmasi tidak lepas dari prinsip-prinsip ulumul hadis yang kuat, seperti disebutkannya sanad secara utuh, dan digunakannya istilah-istilah teknik dalam ulumul hadis. Kegemilangan beliau ini dapat dilihat dari karya-karya beliau khsushnya terkait dengan bidang hadis. Saat menyususun kitab al-Minhah al-Khairiyah, beliau mengutamakan hadis-hadis dengan sanad yang tinggi (isnad 'adli), dan tak lama kemuadian mensyarhnya. Dari sini terlihat kemampuan luar biasa beliau dalam bidang hadis. ${ }^{55}$

Tidak hanya pada karya itu saja, beliau juga menunjukkan keahlian beliau dalam bidang hadis dengan mengarang kitab-kitab lainnya, seperti kitab 'Ināyah al-Muftaqir

${ }^{54}$ Muhammad Mahfudz al-Tarmasi. Kifāyah al-Mustafid limā' 'Alā min Asānīd, h. 12 .

55 Muhammad Muhajirin, Mahfudz al-Tarmasi: Ulama Hadis Nusantara Pertama, h. 45.

TAHDIS Volume 9 Nomor 2 Tahun 2018 
bimā Yata'allaq bi Sayyidinā al-Khadhir yang juga merupakan salah satu kitab karya Syekh Mahfudz dalam bidang hadis, dan merupakan saduran dari kitab al-Ishabah fi Tamyiz al-Shahabah karya Ibn Hajar al-Asqalani yang menyingkap misteri Nabi Khidir as. Beliau al-Tarmasi dalam awal muqadimahnya menyertakan sanad beliau yang sampai pada Ibn Hajar alAsqalani. ${ }^{56}$ Kitab ini merupakan kitab yang langka yang membicarakan Nabi Khidir as. Dalam catatan sejarah umat Islam, kaum yang memegang teguh keyakinan bahwa Khidir as adalah Nabi dan masih hidup sampai sekarang pada umumnya adalah kaum sufi, sedangkan yang menolak keyakinan itu umumnya adalah fuqaha. Para ahli hadis sendiri dalam sejarahnya lebih sering dekat dengan para fuqaha, sehingga tidak mengherankan bila Ibn Hajar sebagai seorang ahli hadis terkemuka memiliki keyakinan yang sama dengan para fuqaha. Al-Tarmasi sendiri dalam hal ini berusaha mengambil jalan tengah dengan mereposisikan dirinya sebagai ahli hadis yang memiliki kecenderungan sufiistik. Beliau dengan karyanya kitab ini mengantarkan kepada keyakinan bahwa Khidir as adalah seorang Nabi yang masih hidup sampai sekarang, bahkan sampai akhir zaman sesuai dengan kehendak Allah SWT. ${ }^{57}$

Pada karya beliau Manhaj Dzawi al-Nadzar fi al-Syarh Alfiah 'Ilm Asar yang merupakan karya yang membicarakan ilmu mushtalah hadis Syarah atas karangan Imam Jalaluddin alSuyuthi juga menyertakan garis sanad beliau hingga sampai pada al-Syuyuti. ${ }^{58}$ Kitab ini merupakan satu di antara karya besar al-Tarmasi. Kitab ini beliau tulis dalam waktu 4 bulan 14

56 Muhammad Mahfudz al-Tarmasi, 'Ināyah al-Muftaqir bimā Yata'allaq bi Sayyidina al-Khadhir, (Demak: Al-Barokah PP. BUQ Betengan, 1428), h. 1.

57 Muhammad Mahfudz al-Tarmasi, 'Ināyah al-Muftaqir bimā Yata'allaq bi Sayyidināal-Khadhir, h. 3.

58 Muhammad Mahfudz al-Tarmasi, Manhaj Dzawi al-Nadzar, (Surabaya: alHaramain, 1974), h. 3. 
hari, waktu yang cukup singkat untuk menghasilkan sebuah karya besar. Akan tetapi seseorang dapat melihat intelektual alTarmasi dalam memahami hadis dan menuangkannya dalam sebuah karya. ${ }^{59}$ Kitab ini secara keseluruh beliau tulis di Makkah dan diselesaikan pada waktu Asyar hari Jum'at pada tanggal 14 Robiul Awal tahun 1329 H. ${ }^{60}$

Dari keterangan di atas terlihat jelas bahwa al-Tarmasi memiliki keilmuan dan intelektualitas yang cukup tinggi, khususnya dalam bidang hadis yang terbukti dengan beberapa karya yang telah dihasilkannya. Atas keaktivan serta produktivitas beliau ini kemudian nama beliau cukup dikenal di kalangan ulama asal Nusantara pada masanya hingga saat ini dan juga di penjuru dunia secara umum.

\section{Kontribusi dalam Bidang Hadis Arba'in.}

Mengenai penghimpunan 40 hadis, al-Tarmasi bukanlah orang yang pertama, melainkan banyak ulama sebelumnya yang telah melakukan penghimpunan 40 hadis ini. Ulama yang pertama kali melakukannya adalah Abdullah ibn Mubarak, Muhammad ibn Aslam al-Tūsi, Hasan ibn Sufyan al-naswi dan Abu Bakar Muhammad ibn Ibrahim al-Ashbahani, Darul Quthni, Abu Abdurrahman al-Salami, Abu Said al-Mayalini, Abu Usman Muhammad ibn Abdillah al-Anshari dan Abu Bakar al-Baihaqi. ${ }^{61}$ Pada karya al-Tarmasi terkait dengan penghimpunan 40 hadis ini beliau susun yang di dalamnya terdapat 22 hadis yang berasal dari Hadits Tsulasiyat al-Bukhari yang beliau peroleh dari guru beliau Syekh al-Sayyid Abu Bakar bin Al-Sayyid Muhammad Syatho, yakni hadis yang antara periwayat sampai

59 Muhammad Muhajirin, Mahfudz al-Tarmasi: Ulama Hadis Nusantara Pertama, h. 87.

${ }^{60}$ Muhammad Mahfudz al-Tarmasi, Manhaj Dzawi al-Nadzar, h. 301.

61 Muhammad Muhajirin, "At-Tarmasi: Icon Baru Hadits Arbai'in di Indonesia," h. 314.

TAHDIS Volume 9 Nomor 2 Tahun 2018 
Rasulullah saw hanya terdapat tiga perowi saja yang menjadikan nilai keshohihannya hadis ini sangat tinggi. ${ }^{62}$ Penulisan kitab ini oleh al-Tarmasi diselesaikan pada hari Ahad tanggal 16 Ramadhan 1313 H.63

Sebagaimana kitab yang memuat 40 hadis menjadikan kitab al-Tarmasi ini lebih dikenal dengan nama Arbai'n alTarmasi. Istilah ini dimaksudkan adalah agar lebih mengenalkan kepada para pembaca khususnya dan kepada seluruh pelajar serta umat Islam Indonesia umumnya, bahwa ada Arba'in lainnya yang sudah sangat familier di Indonesia, ${ }^{64}$ sebab seperti yang dijelaskan di atas bahwa ada banyak ulama yang menyusun kitab yang memuat 40 hadis Rasulullah saw. Pada Arbai'in alTarmasi, beliau mencoba mengakomodir seluruh kitab hadis masyhur dari Kutub al-Sittah, dengan cara mengambil setiap hadis pertama dan terakhir dari keenam kitab hadis masyhur tersebut. Seperti beliau mengambil hadis pertama dan terakhir yang terdapat dalam Shohikh Bukhori, hadis pertama dan terakhir yang terdapat dalam kitab Shohih Muslim, Sunan Tirmizi, Sunan Nasa'i dan seterusnya. Selain itu, al-Tarmasi juga mengutip kitab al-Muwatthok Malik, karena menurutnya seperti yang dikutipnya dari Syekh al-Amir al-Kabir dan Syekh Abdul Ghani al-'Umri bahwa kita al-Muwatthok Malik juga merupakan kitab hadis yang cukup terkenal. ${ }^{65}$

Berkenaan dengan kitab Arba'in Nawawi yang sudah cukup masyhur di Indonesia, memiliki perbedaan dengan Arba'in al-Tarmasi. Perbedaan ini terlihat dari berbagai hal, baik

62 Sutarto (dkk). Kumpulan 40 Hadis Syekh Mahfudz al-Tarmasi, h. 14.

${ }^{63}$ Muhammad Mahfudz al-Tarmasi, Al-Minḥah al-Khairiyyah fi Arba'ín Hadīs min Ahādis Khairilbariyyah, (Demak: Al-Barokah PP. BUQ Betengan, 2008).

64 Muhammad Muhajirin, Mahfudz al-Tarmasi: Ulama Hadis Nusantara Pertama, h. 76.

65 Muhammad Muhajirin, Mahfudz al-Tarmasi: Ulama Hadis Nusantara Pertama, h. 77. 
dari sisi pengambilan riwayat maupun tema-tema yang termuat di dalamnya. Dalam meriwayatkan ke-40 hadis tersebut, alTarmasi terlihat lebih komprehensip dalam mencantumkan silsilah periwayatan hadis yang memiliki ketersambungan sanad langsung kepada Rasulullah saw. Dalam karya beliau ini hampir secara keseluruhan berbeda tema dengan Arba'in Nawawi, kecuali 2 hadis yang sama matannya tetapi berbeda jalur periwayatannya. ${ }^{66}$

Pada Muqodimah Arba'in al-Tarmasi ini diberi kata pengantar oleh Kyai Maimun Zubair al-Saranji yang merupakan pimpinan pesantren di Sarang Jawa Tengah, kemudian masuk pada pembahasan hadis. ${ }^{67}$ Menurut Kyai Maimun Zubair dalam muqodimahnya menyatakan bahwa salah satu alasan alTarmasi mengumpulkan dan membukukan 40 hadis Rasulullah saw ini adalah karena mempercayai dan menyakini hadis Nabi berkenaan dengan pengumpulan 40 hadis dengan berdasarkan pada hadis "Barang siapa yang menjaga 40 hadis tentang urusan dunia, maka Allah menempatkannya di akhirat kelak bersama para ulama dan fuqoha", dan juga pada hadis "barang siapa yang menjaga 40 hadis tentang urusan dunia, maka masuklah ke surga dari pintu mana yang engkau kehendaki".68

Arba'in al-Tarmasi ini berjumlah 53 halaman tanpa ada keterangan apapun kecuali rujukan di bawah uraian hadis yang relatif sederhana dan juga menerangkan kata yang sederhana kata yang mungkin sulit dibaca atau dipahami, dan juga terkadang beliau menjelaskan posisi atau bahasa atau cara membacanya, juga menerangkan kata yang dimaksud dari dari

66 Muhammad Muhajirin, Mahfudz al-Tarmasi: Ulama Hadis Nusantara Pertama, h. 78.

67 Muhammad Mahfudz al-Tarmasi, Al-Minhạ al-Khairiyyah fi Arba'în Hadis min Ahadis Khairilbariyyah, Pengantar.

68 Muhammad Mahfudz al-Tarmasi, Al-Minhạ al-Khairiyyah fi Arba'ín Hadīs min Ahädis Khairilbariyyah,Pengantar.

TAHDIS Volume 9 Nomor 2 Tahun 2018 
suatu matan tertentu. ${ }^{69}$ Pada hadis pertama hingga hadis ke sembilan al-Tarmasi mengawali penyebutan hadisnya dengan kata bi al-sanadi, kemudian pada hadis ke sepuluh hingga ke 38 mengawali dengan kata wabihi atau wabihi ilaihi, dan pada hadis ke 39 hingga ke 40 kembali lagi dengan mengawali dengan kata bi al-sanadi al-muttasil. ${ }^{70}$

Secara lebih spesifik, uraian sanad sekaligus tema yang beliau tulis mulai dari hadis pertama hingga ke 40 adalah sebagai tabel berikut ${ }^{71}$ :

\begin{tabular}{|l|c|c|c|}
\hline No & $\begin{array}{c}\text { Hadis } \\
\text { ke- }\end{array}$ & Tema & Riwayat \\
\hline 1. & 1 & $\begin{array}{c}\text { Rahmad atau kasih } \\
\text { sayang }\end{array}$ & $\begin{array}{c}\text { Sufyan bin } \\
\text { Uyainah. }\end{array}$ \\
\hline 2. & 2 & $\begin{array}{c}\text { Kedudukan niat atau } \\
\text { keikhlasan }\end{array}$ & Imam Bukhori \\
\hline 3. & 3 & $\begin{array}{c}\text { Keutamaan kebersihan } \\
\text { dan kerapian atau } \\
\text { thaharoh. }\end{array}$ & Imam Muslim. \\
\hline 4. & 4 & $\begin{array}{c}\text { Adab buang air besar } \\
\text { Abu Daud }\end{array}$ & al-Tirmizi \\
\hline 5. & 5 & $\begin{array}{c}\text { Syarat diterimanya sholat } \\
\text { dan shodaqoh }\end{array}$ & al-Nasa'i. \\
\hline 6. & 6 & Sholat di awal waktu & Ibnu Majah \\
\hline 7. & 7 & $\begin{array}{c}\text { Anjuran taat kepada } \\
\text { Rassulullah saw }\end{array}$ & \\
\hline
\end{tabular}

${ }^{69}$ Muhammad Mahfudz al-Tarmasi, Al-Minḥah al-Khairiyyah fi Arba'ín Hadīs min Ahädis Khairilbariyyah, h. 5.

${ }^{70}$ Muhammad Mahfudz al-Tarmasi, Al-Minhaha al-Khairiyyah fi Arba'ín Hadis min Ahādis Khairilbariyyah, h. 6-49.

71 Muhammad Mahfudz al-Tarmasi, Al-Minhaha al-Khairiyyah fi Arba'în Hadis min Ahādis Khairilbariyyah, h. 5-49. 


\begin{tabular}{|c|c|c|c|}
\hline 8. & 8 & $\begin{array}{l}\text { Anjuran membasuh } \\
\text { tangan ketika bangun } \\
\text { tidur }\end{array}$ & Imam Malik \\
\hline 9. & 9 & $\begin{array}{c}\text { Larangan meriwayatkan } \\
\text { hadis maudhu' serta } \\
\text { ancamannya }\end{array}$ & Imam Bukhori \\
\hline 10. & 10 & $\begin{array}{l}\text { Anjuran memakai satir } \\
\text { (pembatas) ketika shalat }\end{array}$ & Imam Bukhori \\
\hline 11. & 11 & $\begin{array}{l}\text { Kebolehan menghadap } \\
\text { tiang masjid ketika sholat }\end{array}$ & Imam Bukhori \\
\hline 12. & 12 & Waktu sholat magrib & Imam Bukhori \\
\hline 13. & 13 & $\begin{array}{c}\text { Anjuran puasa al-syuro } \\
\text { (tanggal } 10 \text { Muharam) }\end{array}$ & Imam Bukhori \\
\hline 14. & 14 & $\begin{array}{l}\text { Anjuran puasa al-syuro } \\
\text { (tanggal } 10 \text { Muharam) }\end{array}$ & Imam Bukhori \\
\hline 15. & 15 & $\begin{array}{c}\text { Seputar sholat mayit yang } \\
\text { punya hutang }\end{array}$ & Imam Bukhori \\
\hline 16. & 16 & $\begin{array}{c}\text { Seputar sholat mayit yang } \\
\text { punya hutang tapi sudah } \\
\text { dibayar }\end{array}$ & Imam Bukhori \\
\hline 17. & 17 & $\begin{array}{c}\text { Tata cara mensucikan alat } \\
\text { masak yang tersentuh } \\
\text { barang haram }\end{array}$ & Imam Bukhori \\
\hline 18. & 18 & $\begin{array}{c}\text { Bolehnya membayar } \\
\text { fidhiyah bagi orang yang } \\
\text { membunuh }\end{array}$ & Imam Bukhori \\
\hline 19. & 19 & Bai'at & Imam Bukhori \\
\hline 20. & 20 & Strategi melihat musuh & Imam Bukhori \\
\hline 21. & 21 & Sifat Nabi saw & Imam Bukhori \\
\hline 22. & 22 & Peristiwa Khaibar & Imam Bukhori \\
\hline
\end{tabular}




\begin{tabular}{|c|c|c|c|}
\hline 23. & 23 & $\begin{array}{c}\text { Perang yang diikuti Nabi } \\
\text { dan larangan membunuh } \\
\text { orang yang telah } \\
\text { bersyahadad }\end{array}$ & Imam Bukhori \\
\hline 24. & 24 & Hukum qisos & Imam Bukhori \\
\hline 25. & 25 & $\begin{array}{l}\text { Pemakaian perabot orang } \\
\text { Majusi atau no-muslim }\end{array}$ & Imam Bukhori \\
\hline 26. & 26 & $\begin{array}{c}\text { Bolehnya makan daging } \\
\text { qurban }\end{array}$ & Imam Bukhori \\
\hline 27. & 27 & $\begin{array}{c}\text { Tiada denda bagi orang } \\
\text { yang membunuh tanpa } \\
\text { sengaja }\end{array}$ & Imam Bukhori \\
\hline 28. & 28 & Hukum qisos & Imam Bukhori \\
\hline 29. & 29 & Tatacara berba'iat & Imam Bukhori \\
\hline 30. & 30 & Zainab binti Jahsyin & Imam Bukhori \\
\hline 31. & 31 & $\begin{array}{c}\text { Fadhilah dzikir, tasbih } \\
\text { dan tahmid }\end{array}$ & Imam Bukhori \\
\hline 32. & 32 & $\begin{array}{c}\text { Kemahiran sahabat dalam } \\
\text { mubarozah pada perang } \\
\text { badar }\end{array}$ & Imam Muslim \\
\hline 33. & 33 & Larangan mencela waktu & Abu Daud \\
\hline 34. & 34 & $\begin{array}{c}\text { Kedudukan manusia di } \\
\text { hadapan Allah }\end{array}$ & Al-Tirmidzi \\
\hline 35. & 35 & $\begin{array}{c}\text { Minum yang } \\
\text { diperbolehkan }\end{array}$ & al-Nasa'i \\
\hline 36. & 36 & Sifat surga dan neraka & Ibnu Majah \\
\hline 37. & 37 & Nama-nama Nabi saw & Imam Malik \\
\hline 38. & 38 & Halal, haram, dan syubhat & Imam Bukhori \\
\hline 39. & 39 & Tanaman surga & Al-Syuyuthi \\
\hline 40. & 40 & Akhir kebahagiaan & Abu Daud \\
\hline
\end{tabular}




\section{Kontribusi dalam Bidang Sanad}

Syekh Mahfudz al-Tarmasi saat melakukan pengembaraan di dalam menuntut ilmu memiliki karya khusus yang mencatat semua sanad dari setiap ilmu yang beliau pelajari dan beliau kumpulkan dalam karyanya yang berjudul Kifayah alMustafid. ${ }^{72}$ Beliau adalah seorang penulis yang produktif dan sering menghabiskan waktunya di sebuah gua di gunung Hira' yang terletak di lembah Makkah untuk mencari inspirasi, lebih produktif menulis, dan untuk mengasingkan diri sebagaimana yang dilakukan Rasulullah saw.

Sebagaimana anggapan beliau bahwa isnad merupakan bagian dari agama memberikan pemahaman bahwasanya sebelum masuk pada pembahasan inti tulisan, beliau menuliskan ittisal sanad beliau terlebih dahulu, yakni menuliskan dari mana beliau mendapatkan ijazah ilmu yang akan beliau tuliskan ini. Kemudian pada pembahasan inti beliau juga menyebutkan garis sanad secara utuh. ${ }^{73}$

Al-Tarmasi merupakan tokoh sentral jaringan ulama hadis Indonesia karena faktor kapasitas keilmuan beliau yang luas (khususnya dalam bidang hadis) melalui karya-karya beliau yang mendunia. Semangat kelimuan yang beliau miliki juga ditularkan kepada para ulama Indonesia (khususnya ulamaulama pesantren). Karya beliau yang diakui dan dijadikan sebagai representasi dari keahlian beliau dalam menekuni bidang hadis menjadi indikasi penting terhadap ketokohan beliau sebagai poros terbentuknya jaringan ulama hadis Indonesia.

72 Muhammad Mahfudz al-Tarmasi. Kifāyah al-Mustafid limā'Alā min Asānīd, (Beirut: Darul Basyair al-Islamiyyah, 1408), h. 2.

${ }^{73}$ Muhammad Mahfudz al-Tarmasi, Al-Minhạ al-Khairiyyah fi Arba'în Hadis min Ahadis Khairilbariyyah, h. 6-7.

TAHDIS Volume 9 Nomor 2 Tahun 2018 
Peran ulama hadis Indonesia dalam penyebaran hadis maupun ilmunya baru ditemukan pada abad 19 yang ditandai dengan munculnya Syekh Mahfudz al-Tarmasi yang oleh sebagain besar sejarawan disebut sebagai ulama hadis Indonesia. Dan sejak itulah kajian hadis di Indonesia mengalami perkembangan yang dapat dibuktikan dengan dimulainya pengajaran beberapa kitab hadis di beberapa pesantren, dan perhatian terhadap kajian ini mencapai puncaknya pada abad 20 ditandai dengan beberapa kitab hadis yang dijadikan sebagai bahan ajar kurikulum di pesantren, madrasah bahkan perguruan tinggi.

\section{Kesimpulan}

Syekh Mahfudz al-Tarmasi merupakan ulama besar yang sangat berjasa bagi pengembangan keilmuan Islam khususnya dalam bidang hadis dan ilmunya di dunia dan Indonesia khususnya. Beliau adalah ulama nusantra yang berdomisili di Makkah yang senantiasa menelorkan karya-karya ilmiah yang diakui oleh para ilmuan dunia.

Menurut beliau sanad merupakan hal yang sangat penting karena ia merupakan perisai yang dipunyai oleh orang mukmin. Bahkan oleh para ulama (khususnya ulama hadis yang mempunyai latar belakang pesantren yang kuat) menganggap pentingnya keberadaan sanad sebagai proses transformasi hadis atau apapun bentuk disiplin ilmunya agar proses transformasi hadis atau keilmuan dapat dipertanggung jawabkan.

Keluasan keilmuan Syekh al-Tarmasi sebenarnya tidak terbatas pada disiplin hadis maupun ilmunya saja, akan tetapi juga pada disiplin ilmu lainnya seperti qiro'ah, fiqh dan lain sebagainya. Ulama-ulama Nusantara sebelum beliau juga banyak yang mempelajari hadis, namun perhatian yang 
diberikan beliau-beliau tidak sebesar perhatiannya al-Tarmasi dalam disiplin hadis maupun ilmunya.

\section{Daftar Pustaka}

Hussin, Hayati (dkk.). "al-Tarmasi: Tokoh Prolifik Dalam Bidang Pengajian Islam”. Jurnal Pengajian Islam. Akademi Islam Kuis. 2 November 2015.

Mohamad, Sabri (dkk). "Syeikh Mahfudz al-Tarmasi: Tokoh Ilmu Qira'at Nusantara”. Prosiding Nadwah Ulama Nusantara (NUN) IV, 25-26 November 2011.

Muhajirin. "At-Tarmasi : Icon Baru Hadits Arbai'in di Indonesia." ASILHA International Conference. 2017.

Muhajirin. Muhammad Mahfudz al-Tarmasi: Ulama Hadis

Nusantara Pertama. Yogyakarta: Idea Press. 2016.

Muhammad, Nurdinah. "Karakteristik Jaringan Ulama

Nusantara Menurut Pemikiran Azyumardi Azra". Jurnal

Substantia, Vol. 14, NO. 1, April 2012.

Su'udi, Hasan. "Jaringan Ulama Hadis Indonesia". Jurnal Penelitian STAIN Pekalongan. Vol. 5, No. 2, November 2008.

Sutarto (dkk). Kumpulan 40 Hadis Syekh Mahfudz al-Tarmasi Yogyakarta: Lingkar Media. 2014.

Al-Tarmasi, Muhammad Mahfudz. 'Ināyah al-Muftaqir bima' Yata'allaq bi Sayyidina al-Khadhir. Demak: Al-Barokah PP. BUQ Betengan. 1428.

Al-Tarmasi, Muhammad Mahfudz. Al-Khil'ah al-Fikriyyah bi Syarkh al-Minhah al-Khairiyyah. Demak: Al-Barokah PP. BUQ Betengan. 2008.

Al-Tarmasi, Muhammad Mahfudz. Al-Minhah al-Khairiyyah fi Arba'inn Hadis min Ahädis Khairilbariyyah. Demak: AlBarokah PP. BUQ Betengan. 2008. 
Al-Tarmasi, Muhammad Mahfudz. Kifayah al-Mustafid limā' 'Ala' min Asānid. Beirut: Darul Basyair al-Islamiyyah. 1408. Al-Tarmasi, Muhammad Mahfudz. Manhaj Dzawi al-Nadzor. Surabaya: al-Haramain. 1974. 